Article

\title{
Chiral Proportions of Nepheline Originating from Low-Viscosity Alkaline Melts. A Pilot Study
}

\author{
Ewald Hej ${ }^{1, *}$ and Friedrich Finger ${ }^{2, *}$ \\ 1 Fachbereich für Geographie und Geologie der Universität Salzburg, Hellbrunnerstraße 34/III, \\ A-5020 Salzburg, Austria \\ 2 Fachbereich für Chemie und Physik der Materialien, Universität Salzburg, Jakob Haringer Straße 2, \\ A-5020 Salzburg, Austria \\ * Correspondence: Ewald.Hejl@sbg.ac.at (E.H.); Friedrich.Finger@sbg.ac.at (F.F.); Tel.: +43-662-8044-5437
}

Received: 14 August 2018; Accepted: 11 September 2018; Published: 18 September 2018

check for updates

\begin{abstract}
Chromatographic interaction between infiltrating solutions of racemic mixtures of enantiomers and enantiomorphic minerals with chiral excess has been proposed as a scenario for the emergence of biomolecular homochirality. Enantiomer separation is supposed to be produced by different partition coefficients of both enantiomers with regard to crystal faces or walls of capillary tubes in the enantiomorphic mineral. Besides quartz, nepheline is the only common magmatic mineral with enantiomorphic symmetry. It crystallizes from $\mathrm{SiO}_{2}$-undersaturated melts with low viscosity and is a promising candidate for chiral enrichment by autocatalytic secondary nucleation. Under liquidus conditions, the dynamic viscosity of silicate melts is mainly a function of polymerization. Melts with low concentrations of $\mathrm{SiO}_{2}(<55 \mathrm{wt} \%)$ and rather high concentrations of $\mathrm{Na}_{2} \mathrm{O}(>7 \mathrm{wt} \%)$ are only slightly polymerized and hence are characterized by low viscosities. Such melts can ascend, intrude or extrude by turbulent flow. Fourteen volcanic and subvolcanic samples from alkaline provinces in Africa and Sweden were chemically analyzed. Polished thin sections containing fresh nepheline phenocrysts were etched with $1 \%$ hydrofluoric acid at $20{ }^{\circ} \mathrm{C}$ for 15 to $25 \mathrm{~min}$. Nepheline crystals suitable for a statistical evaluation of their etch figures were found in four samples. Crystals with chiral etch figures are mainly not twinned. Their chiral proportions in grain percentages of single crystals are close to parity in three samples. Only one sample shows a slight chiral excess $(41.67 \%$ L-type vs. 58.33\% D-type) but at a low level of significance (15 vs. 21 crystals, respectively).
\end{abstract}

Keywords: chirogenesis; enantiomorphism; nepheline; magmatic flow; etch figures

\section{Introduction}

Extraterrestrial scenarios for chiral enrichment [1,2] have recently been favoured by the scientific community because of experimental evidence for enantiomeric excesses induced by circularly polarized light [3], and because of the fascinating challenge of the cometary mission Rosetta and its enantiomer-separating Cometary Sampling and Composition (COSAC) experiment onboard the Philae lander [4-8]. Nevertheless, chiral enrichment of enantiomers by natural chromatographic processes on the early surface of planet Earth is still a matter of debate. One of us (E. Hejl) [9] has proposed a new hypothesis for enantiomer separation in the course of chemical etching of nuclear particle tracks originating from spontaneous or induced fission of ${ }^{238} \mathrm{U}$ or ${ }^{235} \mathrm{U}$, respectively. The hypothesis relies on the principle of liquid chromatography, i.e., on partition of dissolved molecular species between the walls of capillary tubes and a liquid mobile phase. When such tubes or pores occur in an enantiomorphic crystal they are expected to produce a slight separation of dissolved enantiomers. This process can be amplified in the course of downhill infiltration of seepage water. 
Chromatographic enantiomer separation requires different partition coefficients of both enantiomers relative to an enantiopure or chirally enriched stationary phase. In the scenario proposed by HEJL [9], enantiomorphic minerals in the subsoil of an early Precambrian mainland form the stationary phase for infiltrating fluids. Chromatographic separation of dissolved enantiomers might occur either by selective partition on grain boundaries, cracks and cleavage planes, or in tubular cavities produced by natural etching of nuclear particle tracks. This process necessitates a preexisting chiral enrichment of enantiomorphic minerals in a certain volume of rock or soil.

On Earth, only two enantiomorphic mineral species are quite common components of magmatic rocks: quartz and nepheline. These two minerals may be completed by the $\mathrm{SiO}_{2}$-modification tridymite which could have been more frequent on the early Earth, and was recently discovered on planet Mars by the rover Curiosity of the Mars Science Laboratory [10]. Furthermore, the most frequent enantiomorphic mineral besides quartz and tridymite is nepheline. It belongs to the hexagonal system (hexagonal-pyramidal class, with a polar axis of hexagonal symmetry) and to the space-group $P 6_{3}[11,12]$.

Nepheline has been ignored for enantioselective crystallization in general, and for the emergence of biomolecular homochirality in particular. More than 130 years after the discovery of its enantiomorphism [13], nothing is known about the chiral proportions of nepheline in magmatic rocks or on a global scale. This lack of information might be due to the fact that nepheline is optically not active [14], and that both enantiomorphs cannot be distinguished under polarized light. In this context it is important to notice that nepheline crystallizes in a single space group $\left(P 6_{3}\right)$-in contrast to quartz which belongs to a pair of space groups, $P 3_{1} 21$ (right-handed screw) and $P 3_{2} 21$ (left-handed screw), i.e., space groups with screw axes of opposite handedness.

Determination of the absolute structure of enantiomorphic crystals (including handedness) is still a great challenge for experimental crystallography. Among other methods, $\mathrm{X}$-ray diffraction with dispersion correction has been applied to this problem, and also resonant $\mathrm{X}$-ray diffraction techniques have made some progress during the last decades [15]. TANAKA et al. [16] have studied structural chirality by use of circularly polarized resonant X-ray diffraction. They could demonstrate that the measurement of only one space-group forbidden reflection is sufficient to determine the chirality of $\alpha$-quartz or berlinite $\left(\mathrm{AlPO}_{4}\right)$. The term "absolute structural chirality" refers to space groups having screw axes labeled right-handed or left-handed. This concept does not apply to nepheline whose two enantiomorphs belong to the same space group $\left(\mathrm{P}_{3}\right)$.

Based on crystal morphology and optical activity, many investigations were dedicated to chiral proportions of quartz in nature, as for example in graphic granite [17], but strong chiral excess of quartz was neither found on a worldwide nor on a regional scale $[18,19]$. Because of its occurrence in alkaline rocks having crystallized from $\mathrm{SiO}_{2}$-undersatureated low-viscosity melts, nepheline is a more promising candidate for chiral enrichment by autocatalytic secondary nucleation (seeding) than quartz which mainly crystallizes from melts with higher viscosity.

Spontaneous crystallization of almost enantiopure crystals was indeed observed under laboratory conditions [20,21]. Dissolved sodium chlorate $\mathrm{NaClO}_{3}$ is not chiral, but its crystals are optically active and occur in two enantiomorphs. When such crystals precipitate from an aqueous solution of sodium chlorate, they can be either left-handed or right-handed, with corresponding opposite optical activities. In case of precipitation from a stationary-not flowing - solution, almost equal numbers of crystals of both enantiomorphic configurations are formed [20]. On the other hand, when the solution is stirred with a magnetic stirrer during crystallization, it was found that more than $99 \%$ of the crystals had the same handedness. The direction of enantiomorphic excess (either L- or D-crystals) was unpredictable and obviously not controlled by the direction of stirring. KONDEPOUDI et al. [20] have argued that the enantiomorphic excess is due to autocatalytic secondary nucleation and by the suppression of nuclei of the opposite handedness in the course of a competitive nucleation. Analogous seeding effects were observed for stirred solutions of $\mathrm{NaBrO}_{3}$, and for the crystallization of chiral hydrocarbons from a melt [21]. 
If autocatalytic secondary nucleation [20,21] also occurs in magmatic crystallization, we can expect that a turbulent magmatic flow of low viscosity has a better chance to produce chiral excess than a gentle flowing magma with high viscosity. Nepheline, which crystallizes from $\mathrm{SiO}_{2}$ - undersaturated magmas with rather low viscosity, is a potential candidate for enantioselective crystallization. Transition from laminar to turbulent flow is more easily achieved in alkaline or carbonatitic melts than in silica-enriched magmas with high viscosity. The present investigation is a first test for an eventual chiral enrichment of nepheline in alkaline magmatic rocks.

\section{Viscosities, Ascent Rates and Flow Patterns of Magma under Natural Conditions}

Flow patterns of magma depend on viscosity and density as substantial properties of the magma itself, on magma's velocity or ascent rate relative to a solid frame of reference, and on the geometry of the walls that confine the magmatic flow. In contrast to magma densities, which are usually between 2000 and $3000 \mathrm{~kg} / \mathrm{m}^{3}$, viscosities of magma can vary by several orders of magnitude. Magmatic viscosity depends on temperature, the amount of fractional crystallization within the magmatic flow, and on the chemical composition of the molten fraction. The dynamic viscosity $(\eta)$ connects the shear stress $(\tau)$ to the strain rate of a fluid $(\delta v / \delta y=$ velocity gradient perpendicular to planes of equal flow velocities). Silicate melts mainly behave as Newtonian fluids [22], i.e., they show a linear relationship between shear stress and shear rate for any given temperature and pressure $(\delta v / \delta y=\tau / \eta)$. Above liquidus boundary conditions, the dynamic viscosity of a silicate melt is mainly a function of its polymerization [23,24]. In silicate minerals as well as in silicate melts, the $\mathrm{Si}^{4+}$ ions occur in tetrahedral coordination with oxygen over a wide range of temperature and pressure. Each of these oxygen atoms has the potential of bonding to another $\mathrm{Si}^{4+}$ ion which can result in chains, sheets or three-dimensional networks of connected $\mathrm{SiO}_{4}$ tetrahedrons. Such linking of silicate tetrahedrons has been referred to as polymerization $[23,24]$. The equilibrium between various types of oxygen atoms in a silicate melt can be described by the following reaction:

$$
S i-O-S i+M-O-M=2(S i-O-M)
$$

where $M$ is a cation other than $\mathrm{Si}^{4+}$, and the oxygens of the three terms of the equation are called bridging, free and non-bridging oxygens. This equilibrium between oxygen types can be shortly written as

$$
\mathrm{O}^{0}+\mathrm{O}^{2-}=2 \mathrm{O}^{-}
$$

Equilibrium conditions can be associated to the equilibrium constant $K$

$$
K=\frac{\left(O^{-}\right)^{2}}{\left(O^{0}\right)\left(O^{2-}\right)}
$$

where the terms in brackets refer to activities or, in the case of an ideal solution, to molar concentrations of the oxygen species in the melt. A melt with $K=0$ would be one with no reaction between molten $\mathrm{SiO}_{2}$ and molten metal oxide to form non-bridging oxygen. On the other hand, a melt with $K=\infty$ is given when in reaction (1) all the silica or all the metal oxide is consumed to form non-bridging oxygen. Silicate magmas with a higher equilibrium constant $K$ contain less bridging oxygen, are less polymerized and less viscous than melts with a small $K$. For a given pressure, temperature, and composition, the polymerization equilibrium of a silicate melt is realized when the distribution of oxygen species $\left(\mathrm{O}^{0}, \mathrm{O}^{2-}, \mathrm{O}^{-}\right)$minimizes the free energy of the solution [24].

Such estimations were calculated for binary systems of $\mathrm{SiO}_{2}$ on the one hand and $\mathrm{FeO}, \mathrm{MnO}, \mathrm{CaO}$, and $\mathrm{Na}_{2} \mathrm{O}$ on the other hand [24,25]. All curves (Gibbs free energy vs. molar concentration of $\mathrm{SiO}_{2}$ ) show minimum free energies in the vicinity of about $40 \%$ molar concentration of $\mathrm{SiO}_{2}$. For any given concentration of $\mathrm{SiO}_{2}$, the free energy is highest for the system $\mathrm{FeO}-\mathrm{SiO}_{2}$, and becomes smaller in the 
order of MnO-, CaO-, and $\mathrm{Na}_{2} \mathrm{O}$. Consequently, a $\mathrm{Na}_{2} \mathrm{O}-\mathrm{SiO}_{2}$ melt is always less polymerized and less viscous than a $\mathrm{FeO}-\mathrm{SiO}_{2}$ melt with the same $\mathrm{SiO}_{2}$ concentration. In general, melts with cations of high ionization potential are expected to be more polymerized than melts with cations of low ionization potential, as for example $\mathrm{Na}^{+}$or $\mathrm{K}^{+}$. This theoretical implication is well tested by $\mathrm{X}$-ray diffraction studies and NMR spectroscopy of silica glass [26]. At higher pressures ( $>6 \mathrm{GPa}$ ), the degree of polymerization is further complicated by the formation of new oxygen clusters, including 5 - and 6-coordinated $\mathrm{Si}$ and $\mathrm{Al}$ which result in a decrease of non-bridging oxygen $[27,28]$.

Dynamic viscosities of fresh lava flows can be measured with a portable, motor-driven, rotating shear vane that records torque and rotation rate. Alternatively, open magma channels can be used as natural viscometers. Viscosities are calculated from the channel's slope and depth, as well as from flow velocity and density of magma. Both methods were successfully applied to alkali carbonatite lavas of the 1988 eruption of Oldoinyo Lengai, Tanzania [29].

Flow velocities of effusive lava can be determined by observations on the spot [29]. Emplacement velocities of magma injections into fractures or dykes, as well as magma transport rates in volcanic ascent channels can be derived from seismic data. The rate of stress release depends on the viscoelastic properties of rocks and on the rate of magma flow compensating extensional failure in sills or dykes. Seismic model calculations [30] have shown that at a differential pressure of 1000 bars, basaltic magma must be injected at $1000 \mathrm{~m} / \mathrm{s}$ in a 1 m thick extensional dyke in order to produce a magnitude 5 earthquake. Magmatic flow velocities between 1 and $100 \mathrm{~m} / \mathrm{s}$ are quite common when the injected volume and the dimension of extensional failure are smaller.

Transition from laminar to turbulent flow depends on the fluid's density and its dynamic viscosity, as well as on the flow velocity and a characteristic linear dimension of the flow (for example the diameter of a pipe or the depth of a flow with an open, unconstrained surface). The dimensionless Reynolds number $(R e)$ helps to predict flow patterns for different flow situations:

$$
\operatorname{Re}=\rho \cdot v \cdot L / \eta
$$

with $\rho=$ density of the fluid $\left(\mathrm{kg} / \mathrm{m}^{3}\right)$

$v=$ flow velocity $(\mathrm{m} / \mathrm{s})$

$L=$ hydraulic diameter $(\mathrm{m})$

$\eta=$ dynamic viscosity (Pa.s)

Figure 1 is a double-logarithmic cross plot of dynamic viscosity vs. hydraulic diameter, with characteristic Reynolds numbers of 500 and 2500 for various flow velocities. Transition from laminar to turbulent flow usually occurs at a threshold between these $R e$ values. The hydraulic diameter is either the diameter of a cylindrical pipe or the thickness of a dyke. Figure 1 is valid for a magma density of $2800 \mathrm{~kg} / \mathrm{m}^{3}$ (basalt and nephelinite).

By consideration of published dynamic viscosities of various types of magma above liquidus conditions [22,31], and of reasonable dimensions of magmatic channels, critical flow velocities for the transition from laminar to turbulent flow can be predicted in a semi-quantitative way (Figure 1). Low-viscosity melts of carbonatite or nephelinite $\left(\eta<10^{-1}\right.$ Pa.s) can exhibit turbulent flow even at very low flow velocities of less than $1 \mathrm{~cm} / \mathrm{s}$ in a dyke or vent with hydraulic diameters above $10 \mathrm{~m}$. Basaltic melts $(\eta>10$ Pa.s) have a lesser probability of turbulent flow, which may only occur at higher flow velocities and/or in very large volcanic vents. Dry $\mathrm{SiO}_{2}$-rich melts (rhyolite with $\eta>10^{8}$ Pa.s) can never reach turbulence under realistic flow conditions. These predictions are supported by volcanologic field observations [29,32].

Chiral enrichment by seeding [20] requires not only turbulence but also unconstrained dispersion of crystalline nuclei within the entire magmatic volume. This is only possible when the enantiomorphic crystalline species precipitates early from the melt (Figure 2a), and not late under eutectic conditions (Figure 2b). In the latter case, any seeding will be restricted to the interstitial space of individual liquid pores between already crystallized minerals. The same is the case for crystals in individual 
magma droplets suspended in a gaseous phase of a rapidly expanding explosive eruption (Figure 2c). Mutual catalytic influence between liquid interstices or droplets is impossible.

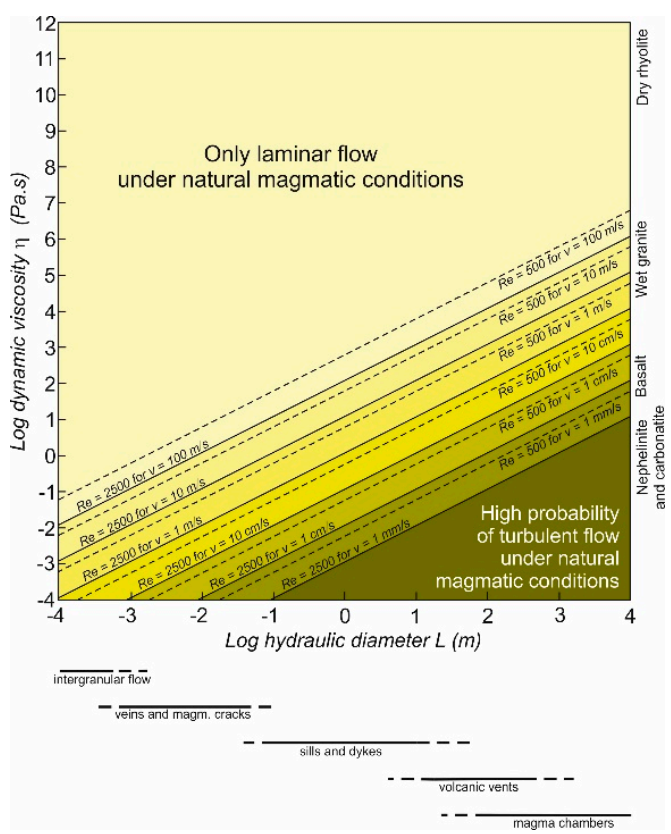

Figure 1. Crossplot of dynamic viscosity $(\eta)$ vs. hydraulic diameter $(L)$ with corresponding Reynold's numbers (both 500 and 2500) for a melt density $(\rho)$ of $2800 \mathrm{~kg} / \mathrm{m}^{3}$, and for various flow velocities $(v)$ between $1 \mathrm{~mm} / \mathrm{s}$ and $100 \mathrm{~m} / \mathrm{s}$. Dynamic viscosities on the right-hand side according to [22,29,31].
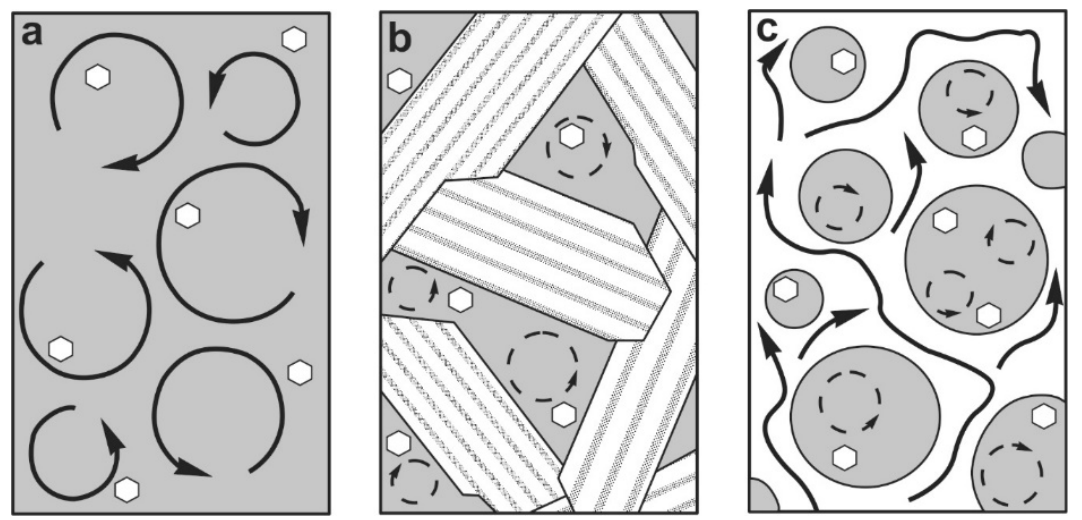

Figure 2. Schematic representation of crystallization under different magmatic conditions. (a) Early unconstrained crystallization in a mainly liquid environment. (b) Late interstitial crystallization in the pores between earlier crystallized phenocrysts. (c) Crystallization in liquid droplets of an expanding current of hot volcanic gas (ignimbrite or pyroclastic flow). Bold circular arrows symbolize turbulent mixing; dashed circular arrows symbolize low probability of turbulence.

Phase relations and the shape of the liquidus surface in the compositional triangle $\mathrm{SiO}_{2}-\mathrm{NaAlSiO}_{4}-\mathrm{KAlSiO}_{4}$ [33-36] help to predict the crystallization behavior of alkaline melts. Figure $3 \mathrm{a}$ shows the liquidus temperatures (isothermal lines) for various compositions at 1 bar $\left(=10^{5} \mathrm{~Pa}\right)$ water-vapor pressure. Early and unconstrained crystallization of nepheline from the melt can only occur in a defined compositional field between the binary eutectic lines in the central part of the diagram and the $\mathrm{NaAlSiO}_{4}$ corner-without the carnegieite field (Figure 3b). Melts with bulk compositions in the nepheline field at some distance from the binary lines will first crystallize nepheline, and by fractional crystallization the composition of the remaining melt will approach the binary eutectic lines. Alkaline rocks with bulk compositions in the quoted nepheline field should have 
porphyritic phenocrysts of nepheline in a finer-grained matrix with a composition that is closer to eutectic conditions.

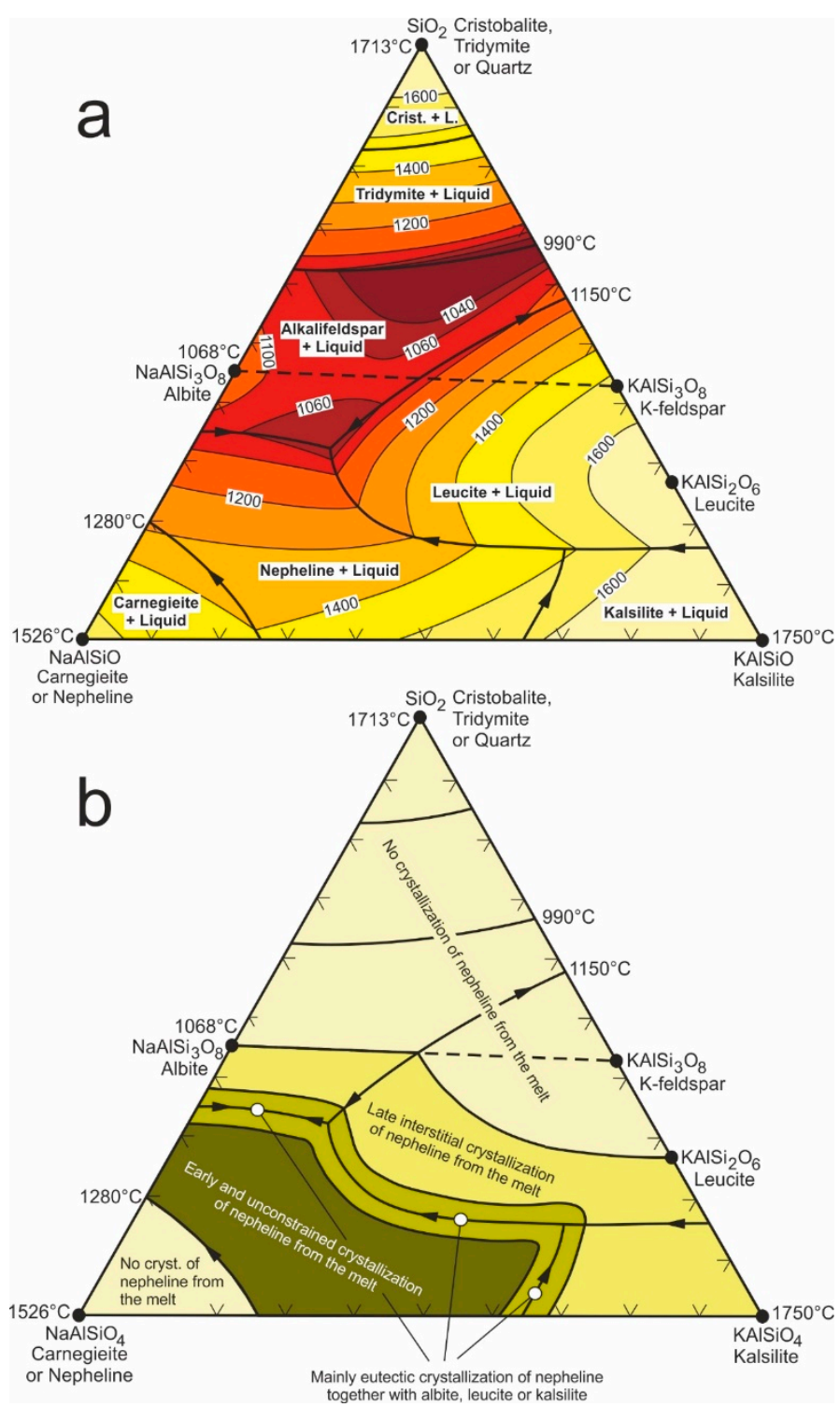

Figure 3. Phase relations in the system $\mathrm{NaAlSiO}_{4}-\mathrm{KAlSiO}_{4}-\mathrm{SiO}_{2}$. The relative proportions of components represent mass concentrations (wt\%). (a) Phase relationships with corresponding liquidus temperatures at 1 bar water-vapour pressure according to [34-36]. (b) Compositional areas with specific crystallization of nepheline (i.e., early, eutectic, or interstitial).

\section{Occurrence, Etching Behavior and Chiral Proportions of Nepheline in Alkaline Igneous Rocks}

Several $\mathrm{SiO}_{2}$-undersaturated magmatic rocks from various alkaline provinces in Africa and northern Europe were chosen for the present investigation. Twelve volcanic rock specimens together with thin sections were provided by curator Epifanio Vaccaro from the Natural History Museum (NHM) of London, another two samples from Namibia were provided by courtesy of Robert Trumbull from the GFZ Potsdam. The absolute structure of nepheline (including handedness) cannot be determined by X-ray diffraction because both enantiomorphs belong to the same space group. For the present study, we decided to determine chiral proportions of polycrystalline nepheline by a statistical evaluation of etch figures on intersecting planes subparallel to the c-axis.

The 14 samples are mainly of volcanic or sub-volcanic origin, two are plutonic rocks, and one is a nepheline-bearing carbonatite (Table 1). Sample no. 1 (BM.1953, 133(2)) is a phonolite from Homa 
Montain (Kenya) which consists of a central area of concentric carbonatite dykes and breccia, and some subordinate plugs of phonolite to nephelinite. K-Ar ages of whole rocks and biotite range from 1.3 to 12 Ma [37]. Sample no. 2 (BM.1965, P19 (6)) is a phonolitic nephelinite from the Dorowa complex in Zimbabwe. This complex is intruded into Archaean granitic gneiss and is mainly composed of syenitic fenite with minor plutonic to subvolcanic intrusions of foyaite, Ijolite, and carbonatite [38]. Sample no. 3 (BM.1968, P37 (401)) is a phonolite from the Namangali hill in southern Malawi. It is composed of phonolitic and feldspathic breccia which forms vents in fenitized gneisses and in Precambrian basement rocks. Both fenites and vent rocks are cut by phonolitic dykes and small carbonatite veins [39]. Samples no. 4, 5, and 6 (BM.1980, P31 $(2,24,27))$ are alkaline volcanic rocks from the Tundulu complex in southern Malawi. Its central subvolcanic area, which comprises carbonatite, agglomerate, trachyte, nephelinite, and phonolite, is surrounded by a broad aureole of fenitized Precambrian basement [40]. Sample no. 7 (BM.1981, P14 (440)) is a nepheline carbonatite from the Alnö complex at the eastern coast of central Sweden. It intruded the Precambrian basement in Late Ediacarian times [41]. Sample no. 8 (BM.1981, P3) is a phonolitic nephelinite from Mt. Etinde in the vicinity of Limbe (Cameroon). Etinde is a steep-sided Late Cenozoic volcano composed of various kinds of nephelinites and nephelinitic tuffs. K-Ar ages of Etinde's volcanic rocks range between 0.065 and 6.3 Ma [42,43]. Samples no. 9 and 10 (BM.1995, P6 (40, 43)) are phonolitic nephelinites from Kerimasi in northern Tanzania. Kerimasi is a Quaternary volcanic cone that rises approximately $1000 \mathrm{~m}$ above the Serengeti Plain. It is mainly built up by nephelinites, corresponding tuffs and agglomerates [44]. Samples no. 11 and 12 (BM.2004, P12 $(28,75))$ are from Oldoinyo Lengai which is situated immediately north of Kerimasi. Because of its natrocarbonatite lavas of extremely low viscosity, Oldoinyo Lengai is one of the most prominent carbonatite volcanoes of the world. Besides carbonatite, it is composed by nephelinites, agglomerates, and tuffs [43,45-47]. It has a Quaternary age and is still active. Samples no. 13 and 14 (KF 85 and KF 88) are nepheline syenites from the Kalkfeld ring complex in northwestern central Namibia. This bimodal carbonatite-alkali silicate complex belongs to the Damaraland Igneous Province which formed in the Early Cretaceous, between 137 and $124 \mathrm{Ma}$ [48]. The Kalkfeld ring complex is hosted in granitic and metasedimentary rocks of the Pan-African Damara System. BÜHN \& TRUMBULL [48] have found that the Kalkfeld silicate magma fractionated alkali-feldspar and nepheline in a $\mathrm{CO}_{2}$-dominated, F- and Ca-poor system, and that euhedral nepheline phenocrysts are rare compared to predominant alkali-feldspar.

Table 1. Rock types and locations of investigated samples.

\begin{tabular}{|c|c|c|c|c|c|}
\hline No. & Sample Code & Rock Type & Location & Coordinates & Ref. \\
\hline 2 & BM.1965, P19 (6) & Phonolitic nephelinite & Dorowa compl., Zimbabwe & $19^{\circ} 04^{\prime} \mathrm{S} ; 31^{\circ} 45^{\prime} \mathrm{E}$ & [38] \\
\hline 4 & BM.1980, P31 (2) & Aegirine biotite phonol. & Tundulu complex, Malawi & $15^{\circ} 32^{\prime} \mathrm{S} ; 35^{\circ} 48^{\prime} \mathrm{E}$ & [40] \\
\hline 5 & BM.1980, P31 (24) & Nephelinite & Tundulu complex, Malawi & $15^{\circ} 32^{\prime} \mathrm{S} ; 35^{\circ} 48^{\prime} \mathrm{E}$ & [40] \\
\hline 6 & BM.1980, P31 (27) & Phonolite & Tundulu complex, Malawi & $15^{\circ} 32^{\prime} \mathrm{S} ; 35^{\circ} 48^{\prime} \mathrm{E}$ & [40] \\
\hline 9 & BM.1995, P6 (40) & Phonolitic nephelinite & Kerimasi, Tanzania & $2^{\circ} 52^{\prime} \mathrm{S} ; 35^{\circ} 57^{\prime} \mathrm{E}$ & [44] \\
\hline 10 & BM.1995, P6 (43) & Phonolitic nephelinite & Kerimasi, Tanzania & $2^{\circ} 52^{\prime} \mathrm{S} ; 35^{\circ} 57^{\prime} \mathrm{E}$ & [44] \\
\hline 11 & BM.2004, P12 (28) & Phonolitic nephelinite & Oldoinyo Lengai, Tanzania & $2^{\circ} 46^{\prime} \mathrm{S} ; 35^{\circ} 55^{\prime} \mathrm{E}$ & [45-47] \\
\hline 12 & BM.2004, P12 (75) & Phonolitic nephelinite & Oldoinyo Lengai, Tanzania & $2^{\circ} 46^{\prime} \mathrm{S} ; 35^{\circ} 55^{\prime} \mathrm{E}$ & [45-47] \\
\hline 13 & KF 85 & Nepheline syenite & Kalkfeld, Namibia & $20^{\circ} 48^{\prime} \mathrm{S} ; 16^{\circ} 07^{\prime} \mathrm{E}$ & [48] \\
\hline
\end{tabular}

Aliquots of samples no. 1 to 12 were ground to a fine powder in an agate mill. Chemical analyses were conducted by classical XRF methods on lithium tetraborate glass beads and pressed powder pellets using a Bruker Pioneer S4 crystal spectrometer at the Department for Chemistry and Physics of Materials, University of Salzburg. Obtained net count rates on single X-ray lines were recast into concentration data ( $\mathrm{wt} \%$ and $\mathrm{ppm}$ ) based on an in-house calibration routine that involves measurements of $\sim 30$ international geostandards (USGS and GSJ). The calibration relies on the Bruker 
AXS software SPECTRAplus FQUANT (v1.7) and corrects absorption, fluorescence and line overlap effects. In addition, a monitor standard (GSJ Granodiorite JG-1a) was measured together with the samples. Analytical results of Table 2 include information on detection limits and typical analytical uncertainties for single elements. Reported errors are conservative and refer not only to the XRF counting statistics, but consider also the uncertainty of the linear fit of the calibrations. Loss on ignition (LOI) was determined gravimetrically after heating the dried samples to $1050{ }^{\circ} \mathrm{C}$ for two hours. Samples no. 13 and 14 had been already analyzed by BÜHN \& TRUMBULL [48].

Table 2. Chemical compositions of investigated samples. L.O.I. = loss on ignition; bdl. = below detection limits. Total iron is given as $\mathrm{Fe}_{2} \mathrm{O}_{3}$. The CIPW Norm (cf. text) was calculated with an assumed ratio of $\mathrm{Fe}^{3+} /$ (total iron) $=0.5$.

\begin{tabular}{|c|c|c|c|c|c|c|c|c|c|c|c|c|}
\hline No. & 1 & 2 & 3 & 4 & 5 & 6 & 7 & 8 & 9 & 10 & 11 & 12 \\
\hline \multicolumn{13}{|c|}{ Major elements (wt\%) } \\
\hline $\mathrm{SiO}_{2}$ & 52.04 & 45.71 & 53.82 & 51.45 & 34.99 & 46.87 & 18.75 & 45.25 & 47.65 & 46.49 & 48.32 & 45.67 \\
\hline $\mathrm{TiO}_{2}$ & 0.52 & 0.65 & 0.75 & 0.42 & 3.10 & 1.22 & 1.31 & 1.11 & 1.21 & 1.48 & 1.06 & 1.02 \\
\hline $\mathrm{Al}_{2} \mathrm{O}_{3}$ & 19.95 & 16.03 & 19.89 & 19.06 & 10.32 & 19.24 & 8.89 & 19.05 & 15.92 & 17.51 & 17.17 & 17.05 \\
\hline $\mathrm{Fe}_{2} \mathrm{O}_{3}$ & 6.28 & 7.46 & 3.81 & 5.71 & 11.05 & 5.93 & 9.17 & 6.74 & 9.68 & 8.82 & 7.52 & 7.27 \\
\hline $\mathrm{MnO}$ & 0.30 & 0.15 & 0.19 & 0.44 & 0.19 & 0.21 & 0.30 & 0.37 & 0.28 & 0.24 & 0.22 & 0.21 \\
\hline $\mathrm{MgO}$ & 0.33 & 3.60 & 0.88 & 0.16 & 14.72 & 1.29 & 1.30 & 1.23 & 1.07 & 1.63 & 0.42 & 0.42 \\
\hline $\mathrm{CaO}$ & 1.97 & 7.64 & 2.16 & 1.63 & 12.18 & 3.82 & 33.46 & 6.32 & 8.07 & 6.93 & 3.97 & 5.26 \\
\hline $\mathrm{Na}_{2} \mathrm{O}$ & 6.40 & 11.55 & 9.96 & 7.51 & 3.00 & 8.68 & 2.95 & 8.10 & 8.54 & 9.29 & 10.05 & 9.51 \\
\hline $\mathrm{K}_{2} \mathrm{O}$ & 7.19 & 1.62 & 5.72 & 7.97 & 3.21 & 7.43 & 1.56 & 6.09 & 5.31 & 4.99 & 5.88 & 5.71 \\
\hline $\mathrm{P}_{2} \mathrm{O}_{5}$ & 0.08 & 1.21 & 0.20 & 0.17 & 1.12 & 0.25 & 1.89 & 0.16 & 0.34 & 0.46 & 0.14 & 0.61 \\
\hline $\mathrm{SO}_{3}$ & 0.12 & 0.44 & 0.25 & 0.10 & 0.39 & 0.11 & 0.21 & 0.29 & 0.05 & 0.11 & 0.22 & 0.17 \\
\hline $\mathrm{F}$ & 0.17 & 0.20 & 0.20 & 0.22 & 0.43 & 0.31 & 0.18 & 0.32 & 0.18 & 0.21 & 0.27 & 1.25 \\
\hline L.O.I. & 4.77 & 3.64 & 1.66 & 4.35 & 4.83 & 3.70 & 18.91 & 3.51 & 1.16 & 1.26 & 4.04 & 5.06 \\
\hline Total & 100.12 & 99.90 & 99.49 & 99.19 & 99.53 & 99.06 & 98.88 & 98.54 & 99.46 & 99.42 & 99.28 & 99.21 \\
\hline \multicolumn{13}{|c|}{ Trace elements (ppm) } \\
\hline $\mathrm{Ba}$ & 2272 & 980 & 705 & 286 & 2986 & 1942 & 1055 & 3370 & 1760 & 1333 & 1716 & 1923 \\
\hline $\mathrm{Ce}$ & 248 & 39 & 273 & 375 & 232 & 185 & 1284 & 212 & 270 & 246 & 249 & 115 \\
\hline $\mathrm{Cl}$ & 626 & 146 & 1739 & 90 & 173 & 886 & 71 & 2619 & 231 & 1184 & 1491 & 319 \\
\hline $\mathrm{Co}$ & 5 & 20 & 8 & 4 & 57 & 8 & 17 & 8 & 9 & 15 & 9 & 8 \\
\hline $\mathrm{Cr}$ & 8 & 32 & 28 & 8 & 384 & 28 & 26 & 14 & 22 & 70 & 10 & 3 \\
\hline $\mathrm{Ga}$ & 40 & 20 & 25 & 42 & 13 & 26 & 10 & 26 & 32 & 28 & 30 & 33 \\
\hline $\mathrm{La}$ & 122 & 20 & 169 & 167 & 123 & 112 & 647 & 175 & 161 & 143 & 156 & 98 \\
\hline $\mathrm{Nb}$ & 278 & 55 & 193 & 749 & 99 & 202 & 528 & 343 & 190 & 156 & 159 & 132 \\
\hline $\mathrm{Nd}$ & 41 & 11 & 51 & bdl. & 84 & 22 & 525 & 4 & 69 & 83 & 65 & 15 \\
\hline $\mathrm{Ni}$ & 9 & 26 & 13 & 10 & 399 & 20 & 13 & 9 & 13 & 14 & 8 & 8 \\
\hline $\mathrm{Pb}$ & 37 & 24 & 20 & 30 & 5 & 6 & bdl. & bdl. & 29 & 22 & 25 & 8 \\
\hline $\mathrm{Rb}$ & 186 & 36 & 165 & 222 & 104 & 160 & 14 & 192 & 131 & 95 & 125 & 97 \\
\hline $\mathrm{Sr}$ & 777 & 837 & 511 & 871 & 2267 & 2847 & 6205 & 6184 & 1539 & 1660 & 2201 & 1862 \\
\hline Th & 89 & bdl. & 33 & 107 & 5 & 9 & 38 & bdl. & 29 & 26 & 28 & 7 \\
\hline $\mathrm{U}$ & 13 & bdl. & bdl. & 47 & bdl. & 15 & bdl. & 10 & 5 & bdl. & 7 & 8 \\
\hline $\mathrm{V}$ & 87 & 101 & 42 & 31 & 258 & 91 & 241 & 242 & 189 & 146 & 179 & 172 \\
\hline W & 11 & 16 & 17 & 21 & 7 & 19 & 12 & 17 & 14 & 11 & 19 & 13 \\
\hline$Y$ & 29 & 12 & 30 & 45 & 25 & 23 & 59 & 26 & 33 & 36 & 31 & 45 \\
\hline $\mathrm{Zn}$ & 246 & 114 & 153 & 338 & 101 & 145 & 91 & 210 & 203 & 166 & 187 & 198 \\
\hline $\mathrm{Zr}$ & 985 & 168 & 882 & 4512 & 287 & 815 & 312 & 875 & 587 & 408 & 494 & 516 \\
\hline
\end{tabular}

Except the carbonatite (no. 7, BM.1981, P14 (440)), all samples have low to intermediate $\mathrm{SiO}_{2}$ contents between 34.99 and $53.82 \%$. The nephelinite of sample no. $5\left(34.99 \% \mathrm{SiO}_{2}\right)$ and the carbonatite of sample no. $7\left(18.75 \% \mathrm{SiO}_{2}\right)$ are ultrabasic by definition $\left(<45 \% \mathrm{SiO}_{2}\right)$. All samples are undersaturated in silica (without normative quartz). With regard to molar proportions, 10 samples (except no. 1, 5,7 , and 14) have $\mathrm{Al}_{2} \mathrm{O}_{3}<\left(\mathrm{Na}_{2} \mathrm{O}+\mathrm{K}_{2} \mathrm{O}\right)$, and can be classified as subaluminous to peralkaline in composition-depending on their mafic minerals. In the classification scheme of COX et al. [49], 
all samples-except of the carbonatite (no. 7)—are in the compositional range of phonolite, phonolitic nephelinite and nephelinite. Normative nepheline contents range between $12.46 \%$ (no. 5) and 36.84 (no. 2). Samples no. 5, 6, 7, 8, 9, 10, 11, and 12 exhibit normative leucite (up to $23.55 \%$ in sample no. 6). Twelve samples (except of no. 5 and 7) have normative orthoclase (up to $50.65 \%$ in sample no. 14). Eight samples (except of no. 6, 8, 9, 10, 11, and 12) have normative plagioclase (up to $23.31 \%$ in sample no. 1). Except no. 14, all samples have normative diopside (up to $23.99 \%$ in sample no. 2). Most samples (except of no. 1, 5, 7, and 14) have normative aegirine (up to 14.06 in sample no. 9). The higher normative aegirine contents $(>8 \%)$ coincide quite well with observed aegirine augite in the thin sections. Thus, a certain amount of $\mathrm{Na}_{2} \mathrm{O}$ has been consumed by the growth of pyroxene and cannot be considered for the weight proportions in the system $\mathrm{NaAlSiO}_{4}-\mathrm{KAlSiO}_{4}-\mathrm{SiO}_{2}$ (phase relationships of Figure 3). In this context it is important to note that powdered aliquots of sample no. $3,9,10,11$, and 12 melted during the determination of the loss on ignition. Thus, the bulk composition of the felsic components of sample no. 3, 9, 10, 11, and 12 must be very close to the ternary eutectic in the system $\mathrm{SiO}_{2}-\mathrm{NaAlSiO}_{4}-\mathrm{KAlSiO}_{4}$ (cf. Figure 3a).

After careful examination under a petrographic microscope (cf. Figure 4), polished thin sections of 10 samples were chosen for chemical etching. Sample no. 3 (phonolite) was rejected because it contains no nepheline phenocrysts; sample no. 7 (carbonatite) was rejected because its nepheline is altered and not idiomorphic; samples 13 and 14 were rejected because they either contain no nepheline phenocrysts (no. 13) or only few interstitial phenocrysts of nepheline (no. 14).
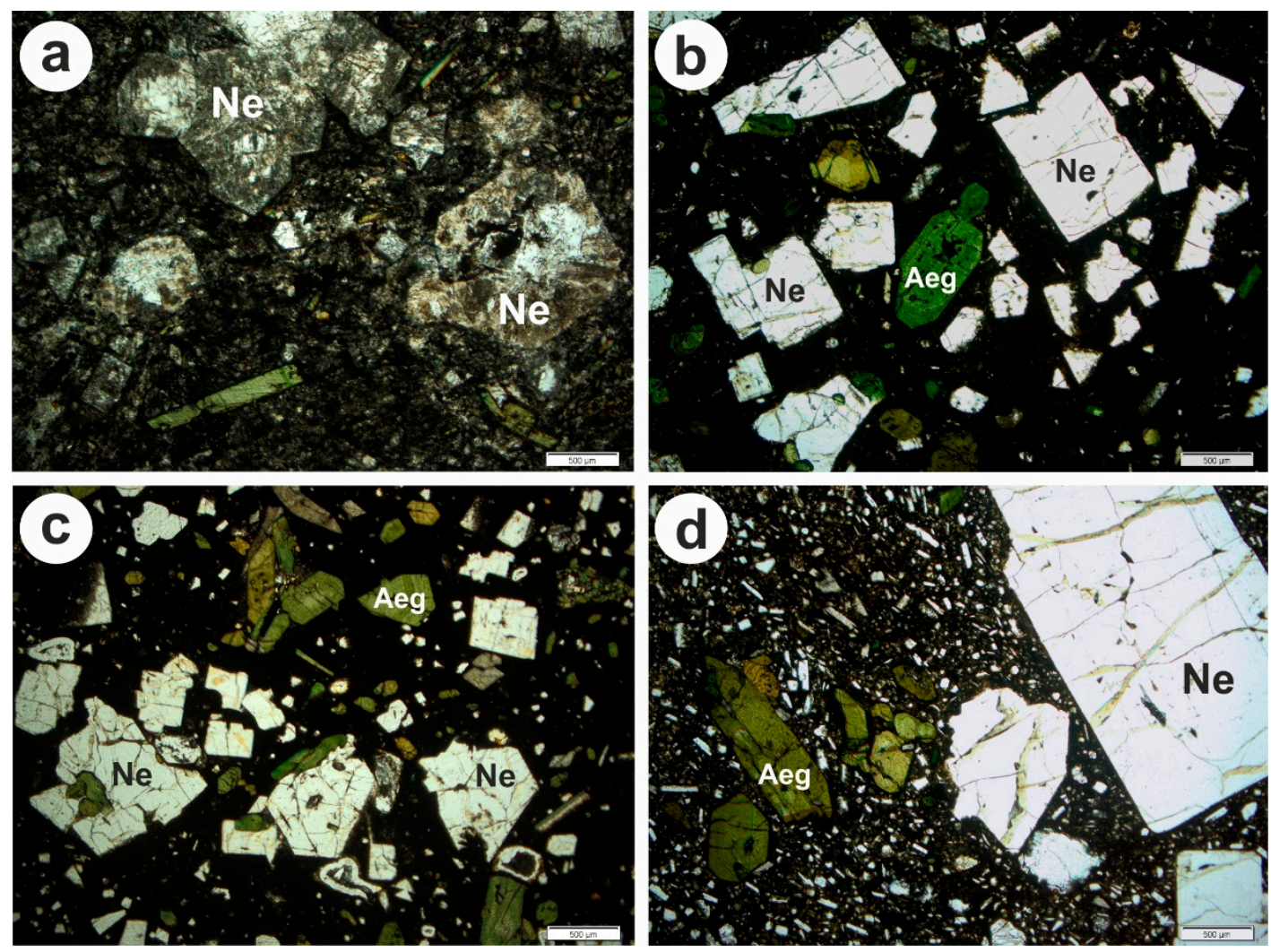

Figure 4. Thin sections of nephelinite samples in transmitted light. (a) Strongly altered nepheline crystals (Ne) in nephelinite from the Tundulu Complex in Malawi; sample no. 6; BM.1980, P31 (27). (b) Porphyric nepheline (Ne) and green aegirine augite (Aeg) in a dark cryptocrystalline matrix; Kerimasi, Tanzania; sample no. 9; BM.1995, P6 (40). (c) Porphyric nepheline (Ne) and green aegirine augite (Aeg) together with fine-grained sanidine in a dark cryptocrystalline matrix; Kerimasi, Tanzania; sample no. 10; BM.1995, P6 (40). (d) Porphyric nepheline (Ne) and green aegirine augite (Aeg) in fine-grained to cryptocrystalline matrix (mainly sanidine); Oldoinyo Lengai, Tanzania; sample no. 11; BM.2004, P12 (28). Scale bars correspond to $500 \mu \mathrm{m}$. 
Etch figures on prism or pyramidal faces of nepheline are highly asymmetric but they have the same orientation as other etch figures of the same crystallographic face $[9,13,14,50,51]$. Such etch figures can be produced with strongly diluted hydrofluoric acid at room temperature and are often depicted in mineralogical textbooks as an example for enantiomorphism (Figure 5). Nepheline can occur as compound twins, the twinning planes being the base and/or a second order prism [14]. In the course of etching, the shape of the etch figures evolves in a characteristic manner. Initial etch figures are asymmetric triangles. They become arcuate with progressive etching, and finally exhibit a drop-shaped form with strong asymmetry. The evolution schema of Figure 6 is a compilation from BAUMHAUER [13,50], TRAUBE [14], and observations of HEJL [9,51].
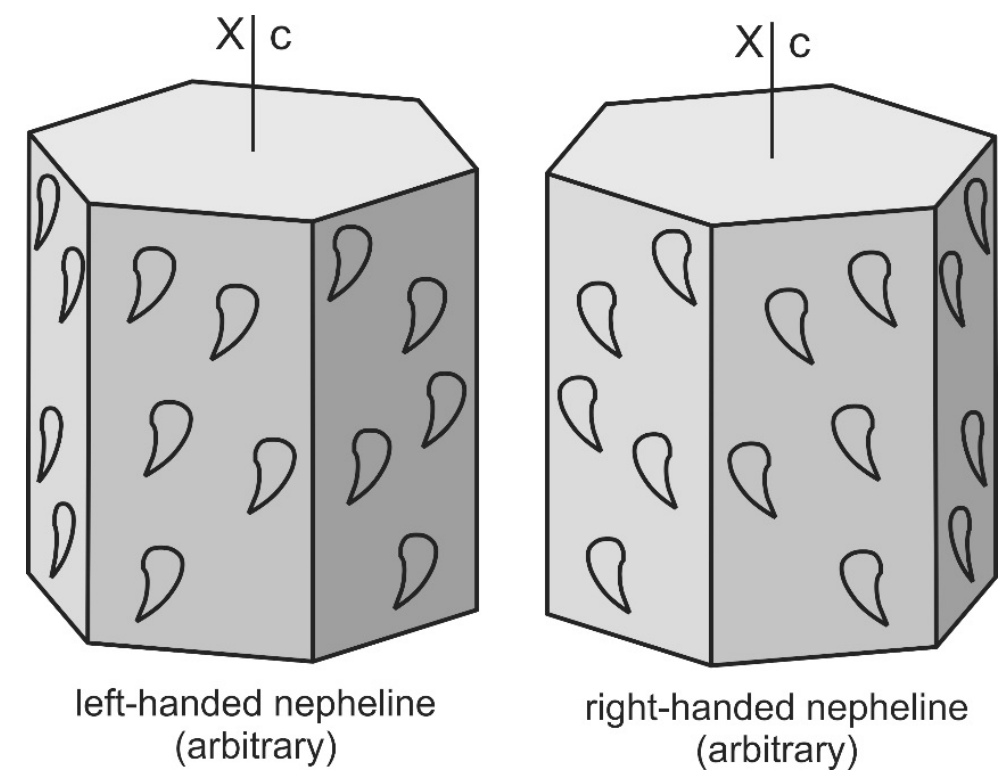

Figure 5. Idealized enantiomorphic single crystals of nepheline with asymmetric etch figures according to $[13,14,50,51]$. The hexagonal crystallographic c-axis corresponds to the $\mathrm{X}$-axis of the optical indicatrix.

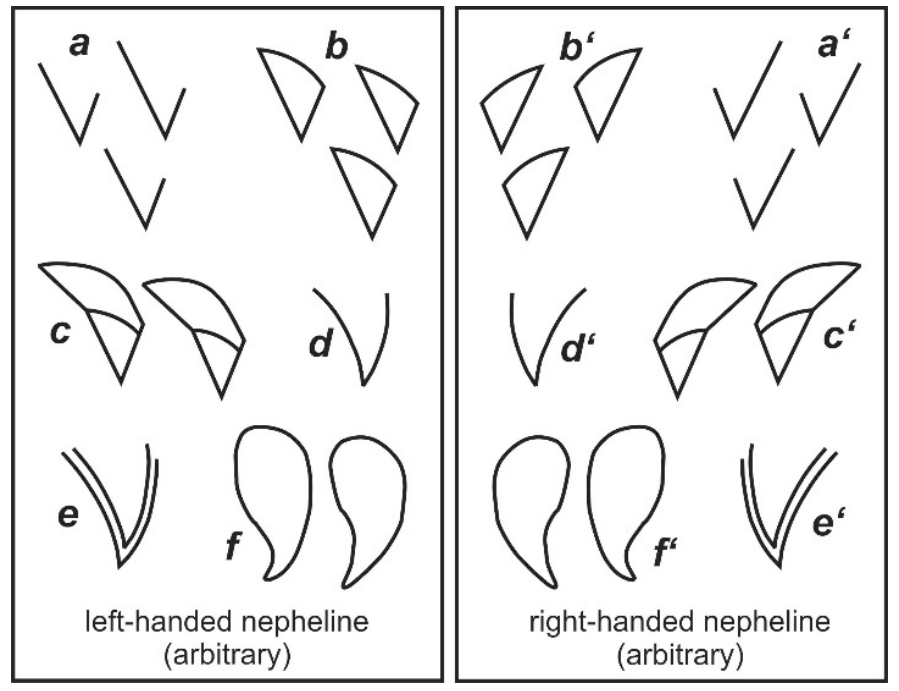

Figure 6. Typical shapes of asymmetric etch figures on prism faces of nepheline, depending on the handedness of the crystal $[13,14,50,51]$.

Thin sections of 10 samples (i.e., all samples of Tables 1-3, except no. 3, 7, 13, and 14) were step-etched with $1 \mathrm{wt} \% \mathrm{HF}$ at $20^{\circ} \mathrm{C}$ for 20 to $35 \mathrm{~min}$. Etch figures of nepheline in the thin sections no. $9,10,11$, and 12 became visible after $15 \mathrm{~min}$ and were almost perfect after $25 \mathrm{~min}$ of etching. Etching of thin section 1 was terminated after $20 \mathrm{~min}$ because no typical etch figures became visible 
on the fine grained and partly altered nepheline. Etching of thin section no. 2 did not produce any etch figures after 35 min. Etching of thin Sections no. 4 and 5 was terminated after 20 min because only indistinct etch figures became visible. Etching of thin section no. 6 was etched for 35 min and did not exhibit any etch figures. Thin Section no. 8 was etched for $20 \mathrm{~min}$; it exhibits few and mainly indistinct etch figures. Thus, characteristic asymmetric etch figures could only be produced in the thin sections of four samples (Table 3). Such etch figures at various stages of development are shown in Figure 7. They can be easily identified as either left-handed or right-handed by comparison with the development sequences of Figure 6.

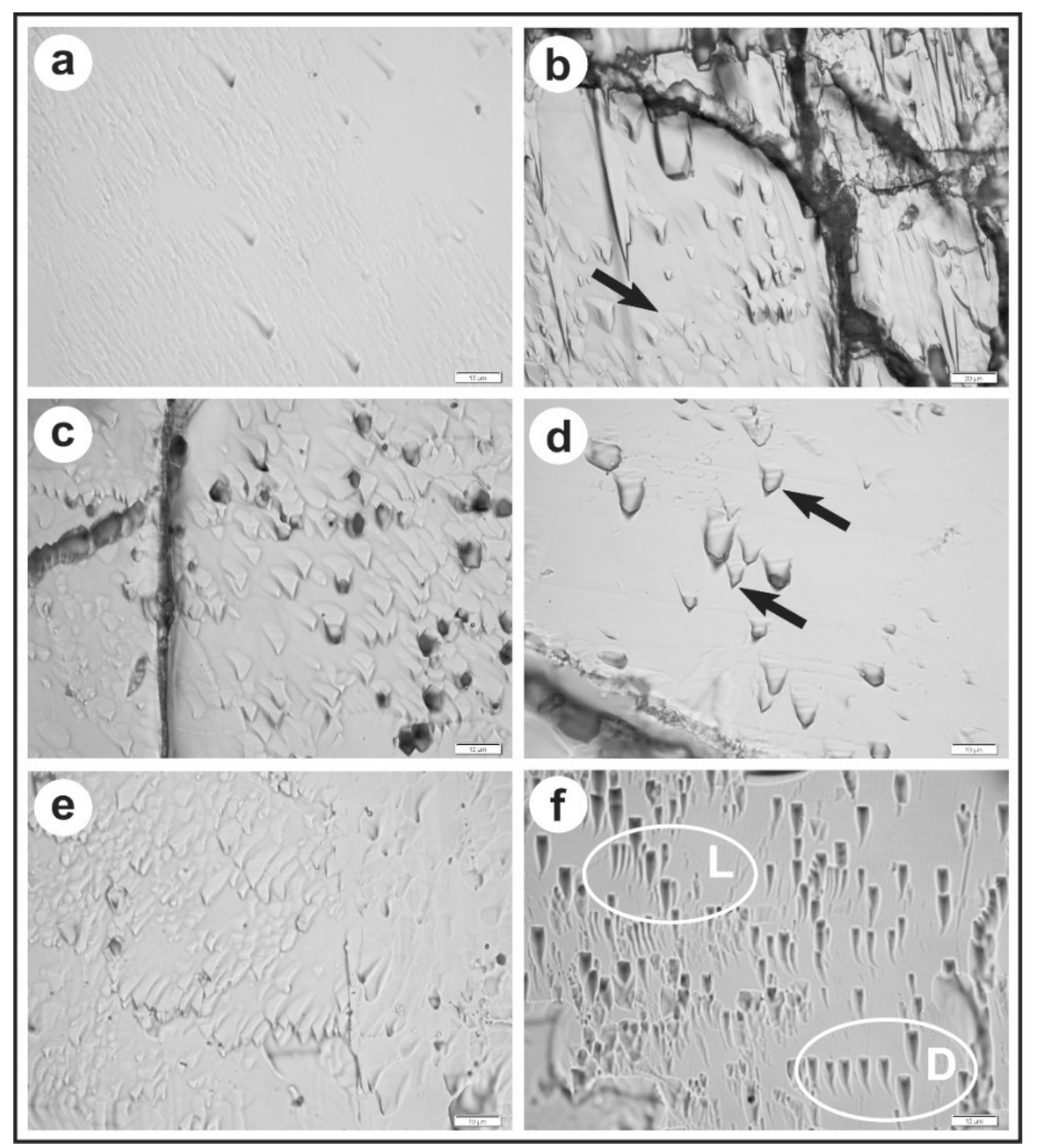

Figure 7. Etch figures on nepheline crystals from East African nephelinite samples. (a) Left-handed etch figures (type a) in sample no. 9, BM.1995, P6 (40). (b) Left-handed etch figures (arrow: type b) in sample no. 9. (c) Left-handed etch figures (mainly type c) in sample no. 9. (d) Left-handed etch figures (arrow: type d) in sample no. 11, BM.2004, P12 (28). (e) Right-handed etch figures (mainly type $\mathrm{c}^{\prime}$ ) in sample no. 9. (f) left-handed (L) and right-handed (D) etch figures (type $\mathrm{f}$ and $\mathrm{f}^{\prime}$, respectively) in a twinned crystal of sample 10, BM.1995, P6 (43). Scale bars correspond to lengths of $10 \mu \mathrm{m}$ (a,c-f), and $20 \mu \mathrm{m}(\mathbf{b})$. 
Table 3. Chiral proportions of nepheline crystals in investigated samples.

\begin{tabular}{|c|c|c|c|c|c|c|c|c|c|c|c|}
\hline \multirow{3}{*}{ No. } & \multirow{3}{*}{ Remarks } & \multicolumn{10}{|c|}{ Counting Statistics } \\
\hline & & \multicolumn{2}{|c|}{ Indistinct } & \multicolumn{2}{|c|}{ Twins } & \multicolumn{2}{|c|}{ L-Type } & \multicolumn{2}{|c|}{ D-Type } & \multicolumn{2}{|c|}{ Total } \\
\hline & & $\mathrm{n}$ & $\%$ & $\mathrm{n}$ & $\%$ & $\mathrm{n}$ & $\%$ & $\mathrm{n}$ & $\%$ & $\mathbf{n}$ & $\%$ \\
\hline 1 & $\begin{array}{l}\text { fine-grained matrix with few altered } \\
\text { phenocrysts of nepheline and sanidine }\end{array}$ & - & - & - & - & - & - & - & - & - & - \\
\hline 2 & $\begin{array}{l}\text { fine-grained matrix with some small nepheline } \\
\text { phenocrysts; no etch figures }\end{array}$ & - & - & - & - & - & - & - & - & - & - \\
\hline 3 & $\begin{array}{l}\text { sanidine phenocrysts }(>5 \mathrm{~mm}) \text { in fine-grained } \\
\text { matrix; no neph. phenocrysts }\end{array}$ & - & - & - & - & - & - & - & - & - & - \\
\hline 4 & $\begin{array}{l}\text { altered phenocrysts of sanidine and aegirine in } \\
\text { a fine-grained matrix }\end{array}$ & - & - & - & - & - & - & - & - & - & - \\
\hline 5 & $\begin{array}{l}\text { few large nepheline phenocrysts }(>5 \mathrm{~mm}) \text { in a } \\
\text { cryptocrystalline matrix }\end{array}$ & - & - & - & - & - & - & - & - & - & - \\
\hline 6 & $\begin{array}{l}\text { cryptocryst. matrix with altered pheno-crysts } \\
\text { of leucite and few nepheline }\end{array}$ & - & - & - & - & - & - & - & - & - & - \\
\hline 7 & $\begin{array}{l}\text { medium-grained fabric of carbonate, aegirine, } \\
\text { and altered nepheline }\end{array}$ & - & - & - & - & - & - & - & - & - & - \\
\hline 8 & $\begin{array}{l}\text { dark cryptocrystalline matrix with leucite, } \\
\text { nosean, and few nepheline }\end{array}$ & - & - & - & - & - & - & - & - & - & - \\
\hline 9 & $\begin{array}{l}\text { many fresh nepheline }(>1 \mathrm{~mm}) \text { and some } \\
\text { aegirine in cryptocryst. matrix }\end{array}$ & 53 & 44.20 & 13 & 10.80 & 28 & 23.30 & 26 & 21.70 & 120 & 100 \\
\hline 10 & $\begin{array}{l}\text { many fresh nepheline }(>1 \mathrm{~mm}) \text { and some } \\
\text { aegirine in cryptocryst. matrix }\end{array}$ & 37 & 46.25 & 7 & 8.75 & 15 & 18.75 & 21 & 26.25 & 580 & 100 \\
\hline 11 & $\begin{array}{l}\text { fresh and big nepheline }(1-7 \mathrm{~mm}) \text { and some } \\
\text { aegirine in fine-grained matrix }\end{array}$ & 23 & 46.00 & 6 & 12.00 & 11 & 22.00 & 10 & 20.00 & 50 & 100 \\
\hline 12 & $\begin{array}{l}\text { slightly alterd nepheline }(1-5 \mathrm{~mm}) \text { and } \\
\text { aegirine in a dark cryptocryst. matrix }\end{array}$ & 25 & 50.00 & 5 & 10.00 & 9 & 18.00 & 11 & 22.00 & 50 & 100 \\
\hline 13 & $\begin{array}{l}\text { porphyric K-feldspar in a groundmass of } \\
\text { medium-grained feldspar and biotite }\end{array}$ & - & - & - & - & - & - & - & - & - & - \\
\hline 14 & $\begin{array}{l}\text { equigranular fabric of perthitic feldspar with } \\
\text { few interstitial nepheline }\end{array}$ & - & - & - & - & - & - & - & - & - & - \\
\hline
\end{tabular}

Statistical proportions of left-handed and right-handed nepheline were determined in the following manner. After etching, the whole area of the thin sections was screened under a petrographic microscope at a magnification of $1250 \times$ for the identification of nepheline. It was decided to determine grain percentages instead of volumetric or mass percentages. Therefore, every discernible nepheline crystal with suitable orientation was recorded one time, regardless of its size. The counted crystals should fulfill the following criteria: they should be idiomorphic, larger than $0.3 \mathrm{~mm}$, and their crystallographic c-axis should be parallel or subparallel to the plane of section (inclination $<20^{\circ}$ ). The latter criterion was tested under the petrographic microscope by the shape of the crystal boundaries and by the interference colors when a gypsum plate is inserted in addition position (thickness of the sections is about $30 \mu \mathrm{m}$ ). The crystals were divided into four classes: crystals without chiral etch figures, twinned crystals with chiral etch figures, single crystals with right-handed etch figures and single crystals with left-handed etch figures. Counting results are given in Table 3.

In exceptional cases a twinning plane can be parallel to the thin section without crosscutting it and would be erroneously counted as single L- or D-type. The twinning plane in Figure $7 \mathrm{f}$ crosscuts the thin section horizontally in the middle of the photograph; the symmetry relations of corresponding etch figures (both $\mathrm{L}$ and $\mathrm{D}$ ) indicate that the twinning plane must be parallel to the c-axis, i.e., in an oblique (acute-angled) position to the section plane. 
In sample no. 9 (BM.1995, P6 (40)) a total of 120 nepheline crystals fulfilling the required conditions was found. Fifty-three of them had only indistinct etch figures, 13 were found to be twins with etch figures of opposite handedness, and 54 had only etch figures of a single chiral type (either only L-type or only D-type). Among the latter, 28 are left-handed and 26 are right handed. Thus, $23.3 \%$ of the crystals are left-handed, 21.7 are right-handed, and 55\% are indistinct or twinned. Among those crystals with distinct chirality, $51.85 \%$ are left-handed and $48.15 \%$ are right-handed.

In sample no. 10 (BM.1995, P6 (43)) a total of 80 nepheline crystals fulfilling the required conditions was found. Thirty-seven of them had only indistinct etch figures, 7 were obviously twinned, and 36 had only etch figures of a single chiral type (either only L-type or only D-type). Among the latter, 15 are left-handed and 21 are right handed. Thus, $18.75 \%$ of the crystals are left-handed, $26.25 \%$ are right-handed, and 55\% are indistinct or twinned. Among those crystals with distinct chirality, $41.67 \%$ are left-handed and $58.33 \%$ are right handed.

It was difficult to find many suitable nepheline crystals in the samples no. 11 and 12 (BM.2004, P12 (28 and 75)). Therefore, only 50 crystals were evaluated in each of them. As in the above-mentioned samples, more than $50 \%$ of the crystals are indistinct or twinned (cf. Table 3). Among the well-defined chiral individual crystals, the proportions are close to parity: 11 L-Type $(52.38 \%)$ vs. 10 D-type $(47.62 \%)$ in sample no. 11; 9 L-type (45\%) vs. 11 D-type (55\%) in sample no. 12.

The level of significance of these statistical proportions can be estimated by the p-value (probability value) which indicates the probability that, when the null hypothesis is true, the deviation from the expected result is the same or greater than that of the actual observed result. The null hypothesis for chiral proportions of nepheline is that both L-type and D-type occur in similar amounts (probability = 0.5 ) and that for a number $n$ of well-defined chiral crystals, the expected number of L-type and D-type crystals is $n / 2$. The calculated p-values for samples no. 9, 10, 11 , and 12 are $0.45,0.20,0.50$, and 0.41 , respectively. Each of these p-values is compatible with chiral parity, but the chiral proportions of sample 9 have the highest probability for a significant chiral excess, because the observed proportions have only a $20 \%$ probability to be found when the null hypothesis is true.

The counting results of nepheline crystals show that most crystals are not twinned and can be assigned as either left-handed or right handed. Measured chiral proportions in three samples are well compatible with chiral parity (no chiral excess). One sample (no. 10, BM.1995, P6 (43)) indicates a slight chiral excess of the D-type at a low level of significance. These findings do not necessarily exclude the possibility that under very special circumstances magmatic nepheline can exhibit a stronger chiral enrichment by autocatalytic secondary nucleation in a turbulent magmatic flow, but they show that this is not the general case.

None of the investigated samples has an Archean age and the sampled alkaline provinces in Africa and Sweden are certainly much younger than the appearance of biomolecular homochirality on planet Earth. Only little alkaline magmatism is known from Precambrian terrains. The oldest well-documented alkaline igneous rocks (leucite trachytes and phonolites) have an age of $2.7 \mathrm{Ga}$ and occur in the Kirkland Lake area of the Superior Province, Canada [52]. To date, no alkaline rocks were reported from terrains older than $2.7 \mathrm{Ga}$. Thus, the time gap between the earliest evidence for life on Earth at $3.7 \mathrm{Ga}[53]$ and the earliest known alkaline rocks is $1.0 \mathrm{Ga}$. Incomplete preservation of alkaline rocks could be due to preferential destruction by erosion of higher continental settings (volcanoes) or to almost complete subduction of alkaline volcanic islands. On the other hand, alkaline magmatic activity could have been rare because the Archean mantle was significantly hotter than today and has produced more extensive partial melting with only very small portions of low-degree melts.

\section{Conclusions and Outlook}

This pilot study has shown that nepheline enantiomorphs in unaltered volcanic rocks can be often identified by the shape of etch figures on section planes subparallel to the crystallographic c-axis. With regard to chiral proportions of nephelines originating from low-viscosity alkaline melts, the following conclusions can be drawn: 
1. Not all the nepheline crystals exhibit chiral etch figures on such section planes. Up to more than $50 \%$ of the crystals with suitable orientation in a thin section do not develop chiral etch figures when they are treated with diluted hydrofluoric acid $\left(1 \% \mathrm{HF}\right.$ aqu. at $\left.20^{\circ} \mathrm{C}\right)$.

2. Twinning occurs in magmatic nepheline but is not ubiquitous. In the investigated samples, most nepheline with chiral etch figures is not twinned.

3. The investigated samples do not exhibit a strong chiral excess of nepheline. Counting statistics of three of four evaluated samples are well compatible with chiral parity; only one sample shows a slight chiral excess (41.67\% L-type vs. $58.33 \%$ D-type) but at a rather low level of significance $(p$-value $=0.20)$ because of the paucity of countable crystals (15 vs. 21 , respectively).

When examples of significant chiral excess of nepheline are found in future research, two important issues need to be addressed:

1. Enantiomer separation by liquid chromatographic interaction between infiltrating molecular solutions and nepheline with chiral excess has not yet been tested in the laboratory.

2. Nepheline bearing rocks are not (yet) known from early Archean terrains. The eldest well-documented nepheline occurrences are about $1 \mathrm{Ga}$ younger than the earliest evidence of life. At the present state of knowledge, this time gap is an obstacle for the validity of the outlined liquid chromatographic hypothesis with nepheline as a stationary phase.

Author Contributions: Conceptualization, E.H.; Methodology, E.H.; Validation, E.H. and F.F.; Investigation, E.H. and F.F.; Resources, E.H. and F.F.; Writing-Original Draft Preparation, E.H. and F.F.; Writing-Review \& Editing, E.H.; Visualization, E.H.; Project Administration, E.H.; Funding Acquisition, E.H.

Funding: This investigation was funded by the Austrian Science Foundation (FWF-Der Wissenschaftsfonds, Fonds zur Förderung der Wissenschaftlichen Forschung) grant number P 30444-N28.

Acknowledgments: Samples no. 1-12 (BM code 1953 to 2004) were kindly provided by the Natural History Museum (NHM) of London (Cromwell Road, South Kensington, SW7 5BD London, United Kingdom). Special thanks to curator Epifanio Vaccaro for his prompt and competent support. Samples no. 13 and 14 (KF 85 and KF 88) were kindly provided by Robert Trumbull (Helmholz Centre Potsdam, GFZ German Research Centre for Geosciences, Telegrafenberg B125, 14473 Potsdam, Germany). Critical suggestions of two anonymous reviewers have helped to eliminate some shortcomings and to improve the overall argumentation.

Conflicts of Interest: The authors declare no conflict of interest.

\section{References}

1. Bailey, J.; Chrysostomou, A.; Hough, J.H.; Gledhill, T.M.; McCall, A.; Clark, S.; Ménard, F.; Tamura, M. Circular polarization in star-forming region: Implications for biomolecular homochirality. Science 1998, 281, 672-674. [CrossRef] [PubMed]

2. Bailey, J. Astronomical sources of circularly polarized light and the origin of homochirality. Orig. Life Evol. Biosph. 2000, 31, 167-183. [CrossRef]

3. Modica, P.; Meinert, C.; de Marcellus, P.; Nahon, L.; Meierhenrich, U.J.; le Sergeant d'Hendecourt, L. Enantiomeric excesses induced in amino acids by ultraviolet circularly polarized light irradiation of extraterrestrial ice analogs: A possible source of asymmetry for prebiotic chemistry. Astrophys. J. 2014, 787, 1-11. [CrossRef]

4. Bibring, J.-P.; Rosenbauer, H.; Boenhardt, H.; Ulamec, S.; Biele, J.; Espinasse, S.; Feuerbacher, B.; Gaudon, P.; Hemmerich, B.; Kletzkine, P.; et al. The Rosetta Lander ("Philae") investigations. Space Sci. Rev. 2007, 128, 205-220. [CrossRef]

5. Goesmann, F.; Rosenbauer, H.; Roll, R.; Szopa, C.; Raulin, F.; Sternberg, R.; Israel, G.; Meierhenrich, U.; Thiemann, W.; Munoz Caro, G.M. COSAC, the cometary sampling and composition experiment on Philae. Space Sci. Rev. 2007, 128, 257-280. [CrossRef]

6. Goesmann, F.; Rosenbauer, H.; Bredehöft, J.H.; Cabane, M.; Ehrenfreund, P.; Gautier, Th.; Giri, Ch.; Krüger, H.; leRoy, L.; MacDermott, A.J.; et al. Organic compounds on comet 67P/Churyumov-Gerasimenko revealed by COSAC mass spectrometry. Science 2015, 349. [CrossRef] [PubMed] 
7. Meierhenrich, U. Amino Acids and the Asymmetry of Life; Springer: Berlin/Heidelberg, Germany, 2008; Volume XII, p. 241. ISBN 978-3-540-76885-2.

8. Meierhenrich, U. Comets and Their Origin. The Tool to Decipher a Comet; Wiley-VCH: Weinheim, Germany, 2015; Volume XXX, p. 352. ISBN 978-3-527-41281-5.

9. Hejl, E. Are fission tracks in enantiomorphic minerals a key to the emergence of homochirality? J. Mineral. Geochem. 2017, 194, 97-106. [CrossRef]

10. Morris, R.V.; Vaniman, D.T.; Blake, D.F.; Gellert, R.; Chipera, S.J.; Rampe, E.B.; Ming, D.W.; Morrison, S.M.; Downs, R.T.; Treiman, A.H.; et al. Silicic volcanism on Mars evidenced by tridymite in high-SiO $\mathrm{S}_{2}$ sedimentary rock at Gale crater. Proc. Natl. Acad. Sci. USA 2016, 113, 7071-7076. [CrossRef] [PubMed]

11. Bannister, F.A. A chemical, optical, and X-ray study of nepheline and kaliophilite. Mineral. Mag. 1931, 22, 569-608. [CrossRef]

12. Buerger, M.J.; Klein, G.E.; Donnay, G. Determination of the crystal structure of Nepheline. Am. Mineral. 1954, 39, 805-818.

13. Baumhauer, H. Ueber den Nephelin. Zeitschrift für Kristallographie-Cryst. Mater. 1882, 6, $209-216$. (In German)

14. Traube, H. Beiträge zur Kenntnis des Nephelins und des Davyns. N. Jb. Min. Geol. Palaeont. 1895, IX, 466-479. (In German)

15. Dmitrienko, V.E.; Ishida, K.; Kirfel, A.; Ovchinnikova, E.N. Polarization anisotropy of X-ray atomic factors and 'forbidden' resonant reflections. Acta Crystallogr. A 2005, 61, 481-493. [CrossRef] [PubMed]

16. Tanaka, Y.; Kojima, T.; Takata, Y.; Chainani, A.; Lovesey, S.W.; Knight, K.S.; Takeuchi, T.; Oura, M.; Senba, Y.; Ohashi, H.; Shin, S. Determination of structural chirality of berlinite and quartz using resonant $\mathrm{X}$-ray diffraction with circularly polarized X-rays. Phys. Rev. B 2010, 81, 144104. [CrossRef]

17. Heritsch, H. Die Verteilung von Rechts- und Linksquarzen in Schriftgraniten [in german]. Tschermaks Miner. Petrogr. Mitt. 1953, 3, 115-125. [CrossRef]

18. Palache, C.; Bermann, G.B.; Frondel, C. Relative frequencies of left and right quartz. In The System of Mineralogy; Frondel, C., Ed.; Wiley: New York, NY, USA, 1962; p. 17.

19. Frondel, C. Characters of quartz fibers. Am. Mineral. 1978, 63, 17-27.

20. Kondepudi, D.K.; Kaufmann, R.J.; Singh, N. Chiral symmetry breaking in sodium chlorate crystallization. Science 1990, 250, 275-276. [CrossRef] [PubMed]

21. Kondepudi, D.K.; Asakura, K. Chiral autocatalysis, spontaneous symmetry breaking, and stochastic behavior. Acc. Chem. Res. 2001, 34, 946-954. [CrossRef] [PubMed]

22. Lesher, Ch.E.; Spera, F.J. Thermodynamic and transport properties of silicate melts and magma. In The Encyclopedia of Volcanoes, 2nd ed.; Sigurdson, H., Ed.; Elsevier: Amsterdam, The Netherlands, 2015; pp. 114-141.

23. Hess, P.C. Polymer model of silicate melts. Geochim. Cosmochim. Acta 1971, 35, 289-306. [CrossRef]

24. Hess, P.C. Polymerization model for silicate melts. In Physics of Magmatic Properties; Hargraves, R.B., Ed.; Princeton University Press: Princeton, NJ, USA, 1980; pp. 3-48.

25. Charles, R.J. The origin of immiscibility in silicate solutions. Phys. Chem. Glasses 1967, 10, 169-178.

26. Jones, A.R.; Winter, R.; Greaves, G.N.; Smith, I.H. MAS NMR study of soda-lime-silicate glasses with variable degree of polymerisation. J. Non Cryst. Solids 2001, 293-295, 87-92. [CrossRef]

27. Lee, S.K.; Cody, G.D.; Fei, Y.; Mysen, B.O. Nature of polymerization and properties of silicate melts and glasses at high pressures. Geochim. Cosmochim. Acta 2004, 68, 4189-4200. [CrossRef]

28. Scarfe, C.M.; Mysen, B.O.; Virgo, D. Pressure dependence of the viscosity of silicate melts. In Magmatic Processes: Physicochemical Principles; Mysen, B.O., Ed.; Special Publication no.1; Geochemical Society: Boston, MA, USA, 1987; pp. 59-67.

29. Dawson, J.B.; Pinkerton, H.; Norton, G.E.; Pyle, D.M. Physicochemical properties of alkali carbonatite lavas. Data from the 1988 eruption of Oldoinyo Lengai, Tanzania. Geology 1990, 18, 260-263. [CrossRef]

30. Shaw, H.R. The fracture mechanisms of magma transport from the mantle to the surface. In Physics of Magmatic Processes; Hargraves, R.B., Ed.; Princeton University Press: Princeton, NJ, USA, 1980; pp. 201-264.

31. Giordano, D.; Russel, J.K.; Dingwell, D.B. Viscosity of magmatic liquids: A model. Earth Planet. Sci. Lett. 2008, 271, 123-134. [CrossRef]

32. Stasiuk, M.V.; Jaupart, C. Lava flow shapes and dimensions as reflections of magma system conditions. J. Volcanol. Geotherm. Res. 1997, 78, 31-50. [CrossRef] 
33. Schairer, J.F.; Bowen, N.L. Preliminary report on equilibrium-relations between feldspathoids, alkali-feldspars, and silica. Trans. Am. Geophys. Union 1935, 16, 325-328. [CrossRef]

34. Schairer, J.F. The alkali-feldspar joint in the system NaAlSiO4-KAlSiO4-SiO2. J. Geol. 1950, 58, $512-517$. [CrossRef]

35. Hamilton, D.L.; MacKenzie, W.S. Phase equilibrium studies in the system NaAlSiO4 (nepheline)-KAlSiO4 (kalsilite). Mineral. Mag. 1965, 34, 214-231. [CrossRef]

36. Winter, J.D. An Introduction to Igneous and Metamorphic Petrology; Prentice Hall: Upper Saddle River, NJ, USA, 2001; p. 699. ISBN 978-0132403429.

37. Le Bas, M.J. Carbonatite-Nephelinite Volcanism; An African Case History; John Wiley: London, UK, $1977 ;$ p. 362. ISBN 978-0471994227.

38. Johnson, R.L. The Shawa and Dorowa carbonatite complexes, Rhodesia. In Carbonatites; Tuttle, O.F., Gittins, J., Eds.; John Wiley: New York, NJ, USA, 1966; pp. 205-224.

39. Garson, M.S. Carbonatites in Southern Malawi; Ministry of Natural Resources Geological Survey Department: Lilongwe, Malawi, 1965.

40. Garson, M.S. The Tundulu carbonatite ring complex in southern Nyasaland. Mem. Nyasaland Geol. Surv. $1962,2,248$.

41. Kresten, P.; Troll, V.R. The Alnö Carbonatite Complex, Central Sweden; Springer: Berlin/Heidelberg, Germany, 2018; Volume XXXI, p. 196. ISBN 978-3-319-9022-1.

42. Nkoumbou, C.; Déruelle, B.; Velde, D. Petrology of Mt. Etinde nephelinite series. J. Petrol. 1995, 36, $373-395$. [CrossRef]

43. Woolley, A.R. Alkaline Rocks and Carbonatites of the World. Part 3: Africa; London Geological Society: London, UK, 2001; p. 372. ISBN 1-86239-083-5.

44. Paslick, C.; Halliday, A.N.; James, D.; Dawson, J.B. Enrichment of the continental lithosphere by OIB melts: Isotopic evidence from the volcanic province of northern Tanzania. Earth Planet. Sci. Lett. 1995, 130, 109-126. [CrossRef]

45. Dawson, J.B. Sodium carbonatite intrusions from Oldoinyo Lengai, Tanzania: Implications for carbonatite complex genesis. In Carbonatites Genesis and Evolution; Bell, K., Ed.; Unwin Hyman: London, UK, 1989; pp. 255-277.

46. Klaudius, J.; Keller, J. Peralkaline silicate lavas at Oldoinyo Lengai, Tanzania. Lithos 2001, 91, $173-190$. [CrossRef]

47. Maarten de Moor, J.; Fischer, T.P.; King, P.L.; Botcharnikov, R.E.; Hervig, R.L.; Hilton, D.R.; Barry, P.H.; Mangasini, F.; Ramirez, C. Volatile-rich silicate melts from Oldoinyo Lengai volcano (Tanzania): Implications for carbonatite genesis and eruptive behavior. Earth Planet. Sci. Lett. 2013, 361, 379-390. [CrossRef]

48. Bühn, B.; Trumbull, R.B. Comparison of petrogenetic signatures between mantle-derived alkali silicate intrusives with and without associated carbonatite, Namibia. Lithos 2003, 66, 201-221. [CrossRef]

49. Cox, K.G.; Bell, J.D.; Pankhurst, R.J. Interpretation of Igneous Rocks; George Allen \& Unwin: London, UK, 1979; p. 450.

50. Baumhauer, H. Ueber die Krystallisation des Nephelin. Zeitschrift für Kristallographie—Cryst. Mater. 1891, 18, 611-618, in German.

51. Hejl, E. First observation of etched uranium fission tracks in nepheline by Hermann Traube (1895)? Mitt. Österr. Miner. Ges. 2017, 162, 83-90.

52. Blichert-Toft, J.; Arndt, N.T.; Ludden, J.N. Precambrian alkaline magmatism. Lithos 1996, 37, 97-111. [CrossRef]

53. Ohtomo, Y.; Kakegawa, T.; Ishida, A.; Nagase, T.; Rosing, M.T. Evidence for biogenic graphite in early Archean Isua metasedimentary rocks. Nat. Geosci. 2014, 7, 25-28. [CrossRef]

(C) 2018 by the authors. Licensee MDPI, Basel, Switzerland. This article is an open access article distributed under the terms and conditions of the Creative Commons Attribution (CC BY) license (http:// creativecommons.org/licenses/by/4.0/). 